\title{
Hygienic Production Practices and Microbial Quality of Cow Milk in Cheha District of Gurage Zone, Southern Ethiopia
}

\author{
Kibebew Babege ${ }^{1 *}$, Mitiku Eshetu ${ }^{2 *}$, Firew Kassa ${ }^{3}$ \\ ${ }^{1}$ Department of Animal Production and Technology, Kebri Dehar University, Kebri Dehar, Ethiopia \\ ${ }^{2}$ School of Animal and Range Sciences, Haramaya University, Dire Dawa, Ethiopia \\ ${ }^{3}$ Holetta Agricultural Research Center, Ethiopia Institute of Agricultural Research, Holetta, Ethiopia \\ Email: *kibebew86@gmail.com, *mitikuguya@yahoo.com
}

How to cite this paper: Babege, K., Eshetu, M. and Kassa, F. (2020) Hygienic Production Practices and Microbial Quality of Cow Milk in Cheha District of Gurage Zone, Southern Ethiopia. Open Journal of Animal Sciences, 10, 592-607.

https://doi.org/10.4236/ojas.2020.103038

Received: May 23, 2020

Accepted: July 21, 2020

Published: July 24, 2020

Copyright $\odot 2020$ by author(s) and Scientific Research Publishing Inc. This work is licensed under the Creative Commons Attribution International License (CC BY 4.0).

http://creativecommons.org/licenses/by/4.0/

\begin{abstract}
The aim of the study was to assess hygienic production practices and to evaluate microbial quality of raw cows' milk in Cheha district of Gurage Zone, Southern Ethiopia. The study was conducted by interviewing 180 smallholder milk producers from two agro-ecologies (highland and midland) and by collecting 40 milk samples from milk producers, small shops, cafes and consumers for microbial quality analysis. The result indicated that majority of the respondents (96.7\%) did not have cow barn and milking area, $57.3 \%$ of them clean their barn once and more than once a week. Moreover, milking without hand washing, absence of udder washing, failure to use towel to clean the udder, and use of plastic pail as milking equipment were practiced by $33.9 \%$, $52.2 \%, 74.4 \%$ and $95.6 \%$ of the respondents, respectively. Furthermore, higher number of respondents (69.4\%) used river water without proper treatment as a major source of water for cleaning purpose and majority of them fail to regularly clean utensils with detergents. Concerning microbial quality, overall mean total bacterial counts (TBC), Coliform counts (CC) and $\mathrm{pH}$ values of milk from current finding were $5.675 \pm 0.016,4.414 \pm 0.017 \log 10 \mathrm{cfu} / \mathrm{ml}$, and $5.963 \pm 0.081$, respectively. In general, overall quality of milk produced as well as marketed in the study area was poor. These were justified from poor hygienic practices and high values of TBC and CC that were significantly higher than the acceptable limits set by Ethiopian Standards for unpasteurized milk. Therefore, adequate sanitary and control measures should be taken at all stages from production to consumer level to produce and supply wholesome milk.
\end{abstract}

\section{Keywords}

Cow Milk, Hygienic Practices, Microbial Quality 


\section{Introduction}

Milk from good hygienic production practices and the udder of a healthy cow contains very few bacteria. But poor hygiene introduces additional bacteria that cause the milk to spoil very quickly. To ensure that raw milk remains fresh for a longer time, good hygiene practices are required during milking and when handling the milk afterwards [1]. Production of quality milk is a complicated process [2]. Milk is a complex biological fluid and by its nature, a good growth medium for many microorganisms, because of its high water content, nearly neutral $\mathrm{pH}$, and variety of available essential nutrients [3]. Therefore, the microbial content of milk is a major feature in determining its quality [4].

Additionally, traditional milk products such as Irgo (traditional Ethiopian yoghurt) and kibe (traditional Ethiopian butter) are also produced using raw milk without any heat treatment. Hence, the possibility of contamination with disease causing organisms is too high [5]. Poor hygiene, practiced by handlers of milk and milk products, may lead to the introduction of pathogenic micro-organisms into the products [6]. Hygienic practices are the major factors to produce safe and quality products for consumption with minimum microbial contamination, and thereby reduce loss of products and improve the position of smallholder milk producers in marketing of quality milk and milk products [7] [8] [9].

Therefore, detail investigation of sanitary condition and microbial quality is very important to identify existing hygiene related problems in order to reduce the risk of public health as well as to improve the livelihood of smallholder dairy farmers by engaging them in quality milk production, handling and marketing of dairy products in the district. However, there is limited study undertaken so far to assess the hygienic milk production and the microbial quality of cow's milk in Cheha district of Gurage Zone. Therefore, this study was designed to assess hygienic milk production practices and identify the microbial quality of cow's milk in Cheha district of Gurage Zone, Southern Ethiopia.

\section{Materials and Methods}

\section{Study Area}

The study was conducted in Cheha district of Gurage Zone, Southern Nations, Nationalities and Peoples Regional State (SNNPRS), Ethiopia. The town of the district, Emdbir, is located at $188 \mathrm{~km}$ south of Addis Ababa. The geographical location of the study area extends from $8^{\circ} 00^{\prime} 18.9^{\prime \prime}$ to $8^{\circ} 15^{\prime} 28.53^{\prime \prime} \mathrm{N}$ latitude and $37^{\circ} 35^{\prime} 46.48^{\prime \prime}$ to $38^{\circ} 03^{\prime} 59.59^{\prime \prime E}$ longitude at an elevation ranging from 1900 to 3000 meters above sea level (m.a.s.l.), and classified under the highland and midland agro-climatic zone. It has a total area of $57,313.85$ ha of which 40,190 ha is cultivated. The average annual rain fall of the area is about $1268.04 \mathrm{~mm}$ and the average maximum and minimum temperature in the study area is $24.97^{\circ} \mathrm{C}$ and $10.69^{\circ} \mathrm{C}$, respectively [10].

\section{Study Procedures}

The study had two parts namely survey and laboratory analysis. Survey part 
was conducted to assess the hygienic milk production practices and the laboratory part, to evaluate microbial quality of milk collected from producers, shops and cafes as well as consumers.

\section{Data Collection and Sampling Technique}

A semi structured questionnaire was used to gather required information on hygienic milk production practices, and the assessment was focused on the following major areas: household characteristics, hygienic practices (housing and cleaning of barn, frequency of cleaning milk containers, washing of udder and milking equipment, source of water, detergents used for washing of the utensils, milking procedures, methods of milk utilization and identify the major constraints related with quality milk production).

The district was stratified as highland and midland based on agro-ecologies. Out of 39 Kebeles located in the district 3 Kebeles were purposively selected from each agro-ecologies, and 30 households per Kebele were selected making a total number of 180 households. Kebeles and participating households were selected with the help of Development Agents (DAs), village leaders and other administrative officials of the District Bureau of Agriculture and Rural Development (Livestock and Fishery office). Households that own at least one local or crossbred milking cow were randomly selected to assess hygienic milk production practices in the district. Following individual interview, focus group discussions were employed to validate the information gathered and to get in-depth information on hygienic milk production practices and related constraints in the district.

Following this assessment and group discussion, a total of 40 samples of raw milk were collected in the morning from previously sampled surveyed respondents, milk sellers (small shops and cafes) around town of the district and consumers across a dairy value chain in the district for the microbiological quality analysis and mean comparison between milk samples collected from different sources in the study area.

Samples of fresh whole milk were collected aseptically following standard procedure [11]. The samples were transported to Wolkyite University Microbiology Laboratory in an icebox and kept in refrigerator at $4^{\circ} \mathrm{C}$ until the time of analysis. Each analysis was made in duplicates. The analysis was performed within 12 hours after sampling [12].

\section{Microbial analysis}

\section{Total Bacterial Count}

For total bacterial count (TBC), appropriate decimal dilutions that would give the expected total number of colonies between 30 and 300 colonies were selected [11]. The molten standard plate count (SPC) agar was cooled to $45^{\circ} \mathrm{C}$ after sterilization before pouring into petridish. One $\mathrm{ml}$ of milk sample was added into sterile test tube containing nine $\mathrm{ml}$ of peptone water up to serial dilution of $10^{-7}$ and mixed thoroughly. Total bacterial count was made after incubating surface plated duplicate decimal dilutions of milk samples at $32^{\circ} \mathrm{C}$ for 48 hours. Finally, colony count was made using colony counter. 


\section{Coliform Count}

After vortexing the sample portion, appropriate decimal dilutions were made by transferring $1 \mathrm{ml}$ of the sample in to $9 \mathrm{ml}$ of peptone water for initial dilution and by transferring $1 \mathrm{ml}$ of the previous dilution into $9 \mathrm{ml}$ of peptone water. After surface plating the appropriate dilution in duplicates on Violet Red Bile Agar (VRBA), Petri dishes were incubated at $32^{\circ} \mathrm{C}$ for 24 hours and counts was made on typical dark red colonies normally measuring at least $0.5 \mathrm{~mm}$ in diameter on uncrowned plates [11]. After counting and recording bacterial colonies in each petri dish, the number of bacteria in milliliter of milk was calculated by the following formula [13].

$$
N=\frac{\sum C}{\left(n_{1} * 2\right)+\left(0.1 * n_{2}\right)} * d
$$

where,

$N=$ Number of colonies per ml of milk sample.

$\Sigma C=$ Sum of all colonies on plates counted.

$n_{1}=$ Number of plates used in lowest dilution counted.

$n_{2}=$ Number of plates used in highest dilution counted.

$d=$ dilution factor of the lowest dilution used.

\section{Milk $\mathrm{pH}$}

The $\mathrm{pH}$ of the milk samples was determined in the laboratory using a digital $\mathrm{pH}$ meter [14]. The $\mathrm{pH}$ meter was calibrated using buffers of $\mathrm{pH} 7.0$ and 4.0 each time before the $\mathrm{pH}$ of milk samples was measured. The milk $\mathrm{pH}$ was measured at laboratory one hour after collection from all milk sources.

\section{Data Analysis}

Data collected from Survey were summarized on Microsoft excel sheet and analyzed using descriptive statistics by using SPSS (statistical package for social science, version 20). Moreover, the major milk quality related constraints were ranked based on the frequency of respondents those gave priority for the problems in the questionnaire and also group discussion was considered. The TBC and CC data were transformed to $\log 10$ values before subjected to statistical analysis. The log transformed values were analyzed using the General Linear Model (GLM) procedure of Statistical Analysis Software (SAS) version 9.0 (2004). Mean comparison was carried out using the Least Significant Difference (LSD) technique when analysis of variance shows significant differences between means and differences were considered statistically significant at 5\% $(P<0.05)$ level of significance.

The following model was used for the analysis of microbial quality of milk:

$$
Y_{i j}=\mu+\beta_{i}+e_{i j}
$$

where,

$Y_{i j}=$ individual observation for each test.

$\mu=$ the overall mean.

$\beta=$ the effect of location (Midland and Highland).

$e_{i j}=$ the error term. 


\section{Results and Discussion}

\section{Barn Facilities and hygiene Practices}

According to the current study most of the respondents (96.7\%) shared the same house with their animals with the intention to protect animals from predators and theft, but only $3.3 \%$ of the respondents were using separate barn for animals (Table 1). Similarly, in west Shewa [15] and in Gurage zone [16] reported that about $91 \%$ - $100 \%$ of the respondents kept their animals in the same house where the family lives. This could probably cause the transmission of disease from animal to human beings and also from human to animal, and affects the quality of milk.

Result of the present study is similar to report from central highland of Ethiopia [9] in which $80.4 \%$ of the respondents were used house type barn. In contrast with present study, the entire interviewed households used fenced barn for overnight cattle holding in Borana zone of Southern Ethiopia [5]. Most of the respondents (91.1\%) in the study area used earthen floor whereas $6.7 \%$ and $2.2 \%$ of them used stone paved and cemented floor house, respectively (Table 1). The present results were comparable with reports from Tigray Regional State that the majority of the respondents $(87.1 \%)$ used earthen type floor and $12.9 \%$ of the respondents were used concrete [17].

The current study showed that about $88.9 \%$ of the respondents used poor quality grass and cereal straw as bedding materials for dairy animals. The use of poor quality bedding materials and earthen floor without any bedding materials in the study area might cause udder and/or teat contamination and attribute to poor quality milk production. Reports from different studies support clean, dry

Table 1. Types of barn and bedding materials used in the study areas $(\mathrm{N}=180)$.

\begin{tabular}{ccccccc}
\hline \multirow{2}{*}{ Variables } & \multicolumn{3}{c}{ Agro-ecology } & \multicolumn{2}{c}{ Overall Mean } \\
\cline { 2 - 6 } & \multicolumn{2}{c}{ HL $(\mathrm{N}=90)$} & ML $(\mathrm{N}=90)$ & \multicolumn{1}{c}{$(\mathrm{N}=180)$} \\
\cline { 2 - 7 } & Freq. & $\%$ & Freq. & $\%$ & Freq. & $\%$ \\
\hline Types of house/Barn & & & & & & \\
Share with family house & 88 & 97.8 & 86 & 95.6 & 174 & 96.7 \\
Fenced/Separate house & 2 & 2.2 & 4 & 4.4 & 6 & 3.3 \\
Materials to construct barn floor & & & & & & \\
Soil/earthen type & 80 & 88.9 & 84 & 93.4 & 164 & 91.1 \\
Concrete & 10 & 11.1 & 2 & 2.2 & 12 & 6.7 \\
Cement & 0 & 0 & 4 & 4.4 & 4 & 2.2 \\
Types of bedding materials & & & & & & \\
Grass and/or cereal straw & 76 & 84.4 & 84 & 93.4 & 160 & 88.9 \\
No bedding materials & 11 & 12.3 & 6 & 6.6 & 17 & 9.4 \\
Saw dust & 3 & 3.3 & 0 & 0 & 3 & 1.7 \\
\hline
\end{tabular}

$\mathrm{HL}=$ High Land, $\mathrm{ML}=$ Mid Land and $\mathrm{N}=$ Number of Respondents. 
and comfortable bedding condition as important factor to minimize the chance of contamination of milk by different microorganism including pathogenic microorganisms [18] [19] [20].

\section{Barn cleaning frequency}

Maintaining the sanitary condition of milking area is an important prerequisite for clean milk production [9]. In the current study, about $42.8 \%$ of the respondents clean their barns daily, while $30.6 \%$ and $26.7 \%$ of the respondents clean their barns 2 - 3 times a week and once a week, respectively. In comparison, respondents $(58.9 \%)$ in the highland area were more experienced in daily barn cleaning practice than respondents (26.7\%) of midland in the study area. This might be the cause of variation in milk quality due to udder contamination with unclean barn. In line with the current finding, about $38.9 \%$ of the respondents clean the barn more than once a week in Borana zone of Southern Ethiopia [5]. Moreover, the majority of the sample respondents (90\%) barn had moderate level of offensive odor, while $10 \%$ of household's barn had high level of offensive odor. This implies that there was high accumulation of feces and urine in the barn or house compound (Table 2). However, proper and clean housing environment is a prerequisite to produce milk and milk products of acceptable quality [18].

\section{Milking and Hygienic Practices}

According to the present findings the entire sample respondents (100\%) in the study areas used hand milking method. Similarly, about all of the households milk their cows by using hand milking either by washing cow teats or letting the calf to suckle to stimulate milk let-down in Shashemene town, Southern Ethiopia [14]. Similarly, about all of the respondents (100\%) were practicing hand milking in Gambella region, Ethiopia [21]. Besides to this, nearly all of the households (96.7\%) milked their cows twice a day, while the remaining 3.3\% of them did milking once a day (Table 3 ). This finding agreed with reports from Borana Zone [5] and Shashemene town [3] who reported that all of the respondents were milked two times a day.

Table 2. Barn cleaning frequency in the study areas.

\begin{tabular}{ccccccc}
\hline & \multicolumn{3}{c}{ Agro-ecology } & \multicolumn{2}{c}{ Overall Mean } \\
\cline { 2 - 7 } Variables & \multicolumn{2}{c}{ HL $(\mathrm{N}=90)$} & ML $(\mathrm{N}=90)$ & \multicolumn{2}{c}{$(\mathrm{N}=180)$} \\
\cline { 2 - 7 } & Freq. & $\%$ & Freq. & $\%$ & Freq. & $\%$ \\
\hline Barn cleaning frequency & & & & & & \\
Daily & 53 & 58.9 & 24 & 26.7 & 77 & 42.8 \\
More than once a week & 29 & 32.2 & 26 & 28.9 & 55 & 30.6 \\
Once a week & 8 & 8.9 & 40 & 44.4 & 48 & 26.7 \\
Level of odor in the barn & & & & & 12.3 & 10 \\
Offensive & 7 & 7.8 & 11 & 12.3 & 18 & 90 \\
Moderate & 83 & 92.2 & 79 & 87.7 & 162 & \\
\hline
\end{tabular}

$\mathrm{HL}=$ High Land, $\mathrm{ML}=$ Mid Land and $\mathrm{N}=$ Number of Respondents. 
Cleaning of the udder before milking is one of the most important hygienic practices required to ensure clean milk production. This is important since the udder of the milking cows could have direct contact with the ground, urine, dung and feed refusals [9]. However, about $52.2 \%$ of sample milk producers in the study area did not washed the udder of milking cows (Table 4). It was reported that insufficient cleaning of the udder may result in contamination of milk [22]. The use of soap and good-quality water for cleaning could be expected to remove milk remains, and microorganisms that affect the microbial quality of milk. In central highlands of Ethiopia [23] and in Shashemene town [3] it was reported that around $72 \%-79 \%$ of the households clean the udder before milking. As opposed to the current study, all respondents from Gurage zone, southern Ethiopia did not wash the udder before milking [6].

Milking in dry condition significantly reduces bacterial count. It is because no surplus water remains on the surface of the udder to drip into the milk and due to less chance of leaching dirt and bacteria from udder, teats and hands into milk [24].

Table 3. Milking procedure and frequency in the study areas.

\begin{tabular}{ccccccc}
\hline & \multicolumn{3}{c}{ Agro-ecology } & \multicolumn{2}{c}{ Overall Mean } \\
\cline { 2 - 7 } Variables & \multicolumn{2}{c}{ HL $(\mathrm{N}=90)$} & ML $(\mathrm{N}=90)$ & \multicolumn{2}{c}{$(\mathrm{N}=180)$} \\
\cline { 2 - 7 } & Freq. & $\%$ & Freq. & $\%$ & Freq. & $\%$ \\
\hline $\begin{array}{c}\text { Milking methods } \\
\text { Strip hand milking }\end{array}$ & 90 & 100 & 90 & 100 & 180 & 100 \\
Milking frequency per day & & & & & & \\
Once & 0 & 0 & 6 & 6.6 & 6 & 3.3 \\
Twice & 90 & 100 & 84 & 93.4 & 174 & 96.7 \\
\hline
\end{tabular}

$\mathrm{HL}=$ High Land, $\mathrm{ML}=$ Mid Land and $\mathrm{N}=$ Number of Respondents.

Table 4. Hand and udder washing practices in the study areas.

\begin{tabular}{ccccccc}
\hline \multirow{2}{*}{ Variables } & \multicolumn{3}{c}{ Agro-ecology } & \multicolumn{2}{c}{ Overall Mean } \\
\cline { 2 - 7 } & \multicolumn{2}{c}{ HL $(\mathbf{N}=90)$} & ML $(\mathrm{N}=90)$ & \multicolumn{2}{c}{$(\mathbf{N}=180)$} \\
\cline { 2 - 7 } & Freq. & $\%$ & Freq. & $\%$ & Freq. & $\%$ \\
\hline Hand washing before milking & & & & & & \\
Yes & 70 & 77.8 & 49 & 54.4 & 119 & 66.1 \\
No & 20 & 22.2 & 41 & 45.6 & 61 & 33.9 \\
Udder washing & & & & & & \\
Udder washing before milking & 31 & 34.5 & 21 & 23.3 & 52 & 47.8 \\
No washing & 40 & 44.4 & 54 & 60 & 94 & 52.2 \\
Use towel to clean the udder & & & & & & \\
Yes & 26 & 28.9 & 20 & 22.2 & 46 & 25.6 \\
No & 64 & 71.1 & 70 & 77.8 & 134 & 74.4 \\
\hline
\end{tabular}

$\mathrm{HL}=$ High Land, $\mathrm{ML}=$ Mid Land and $\mathrm{N}=$ Number of Respondents. 
However, about $74.4 \%$ milking cow owners did not use towel to clean and dry the udder. This might be mainly due to lack of awareness and low level of educational status, absence of training related with hygienic practices in milk production and lack of awareness about the effect of hygiene on milk and milk products quality (Table 4). The current study is in agreement with the findings from Shashemene town, southern Ethiopia that indicated about $71.79 \%$ of smallholder farmers were not using separate towel to clean and dry the udder of milking cows [3].

The milker can be an important source of milk contamination and hence should keep their personal hygiene and be in good health during milking operation [9]. According to the current study, the interviewed smallholder farmers $(66.1 \%)$ washed their hands before milking. In comparison, interviewed respondents $(77.8 \%)$ in the highland area had better hand washing experience than midland respondents (54.4\%). This might be due to lack of awareness about personnel hygiene related with milk contamination and limited water access in the area (Table 4). Similarly, about $30.6 \%$ of the farmers did not wash their hands before milking in West Shoa Zone, Ethiopia [15]. Moreover, about 82.05\% of the milk producers did not wash their hands using detergents prior to milking in Shashemene town, Ethiopia [3].

\section{Udder health problems}

About $67.8 \%$ of the interviewed households in the study areas reported milking cows' udder health problems; which might be due to failure to total remove the milk from the udder during milking, lack of knowledge about prevention and control mechanism of mastitis (Table 5). Similarly, higher proportion of the respondents (97.9\%) experienced udder health problem among the herds in Nuer zone, Gambella region, Ethiopia [21]. It is found that most of the respondents (72.2\%) produced milk from infected udder (during treatment) and supplied to calves while the remaining $20 \%$ of the respondents discard the milk until the end of drug withdrawal period as suggested by animal health technicians (Table 5).

\section{Milk Utensils and Hygiene}

Milking and milk storage utensils need to be properly cleaned and dried in an inverted position prior to use. These are important practices to reduce milk contamination raised from the milk utensils [25]. Moreover, producers should pay particular attention to the type of equipment used. In this regard, aluminum or stainless-steel containers are recommended because of easiness to clean and anti-corrosion properties of the materials as compared to plastic containers [26]. However, majority of the interviewed households (95.6\%) were using plastic containers as milking equipment, while only $4.4 \%$ of them used stainless steel. This might be due to absence of recommended milking and storage equipment in the local market of the study areas (Table 5). In agreement with this finding, plastic containers were frequently used for milking and milk storage in different parts of the country [15] [27].

\section{Water Source for Cleaning Purpose}

Water from non-tap sources used for cleaning can contribute to poor quality milk and milk products. Therefore, it is important that producers should at 
Table 5. Udder/teat health problem and milking equipment.

\begin{tabular}{ccccccc}
\hline \multirow{2}{*}{ Variables } & \multicolumn{3}{c}{ Agro-ecology } & \multicolumn{2}{c}{ Overall Mean } \\
\cline { 2 - 7 } & \multicolumn{2}{c}{ HL $(\mathrm{N}=90)$} & ML $(\mathrm{N}=90)$ & \multicolumn{1}{c}{$(\mathrm{N}=180)$} \\
\cline { 2 - 7 } & Freq. & $\%$ & Freq. & $\%$ & Freq. & $\%$ \\
\hline Yes & 70 & 77.8 & 52 & 57.8 & 122 & 67.8 \\
No & 20 & 22.2 & 38 & 42.2 & 58 & 32.2 \\
Udder/teat health problem & & & & & & \\
Milk produced during treatment & 71 & 78.9 & 59 & 65.6 & 130 & 72.2 \\
Given to calves & 6 & 6.6 & 30 & 33.3 & 36 & 20 \\
Discarded as advised by technician & 8 & 8.9 & 1 & 1.1 & 9 & 5 \\
Given to cats or dogs & 5 & 5.6 & 0 & 0 & 5 & 2.8 \\
Used for home consumption & & & & & & \\
Milking equipment & 83 & 92.3 & 89 & 98.9 & 172 & 95.6 \\
Plastic pail & 7 & 7.7 & 1 & 1.1 & 8 & 4.4 \\
\hline Stainless steel pail & & & & & & \\
\hline
\end{tabular}

$\mathrm{HL}=$ High Land, $\mathrm{ML}=$ Mid Land; and $\mathrm{N}=$ Number of Respondents.

least filter and heat treat water before use [9]. However, as observed in this study, the major source of water available for cleaning was river water (69.4\%) which is utilized without any further treatment. Comparatively higher number of interviewed respondents $(74.4 \%)$ in midland was using river water than highland respondents $(64.5 \%)$, while the rest of them used tap water $(23.9 \%)$ and water from wells (6.7\%) (Table 6). This was mainly due to limited awareness related with the effect of water source on milk and milk products quality, low level of education background, limited tap water access in the area.

The present finding is in line with the report from Gambella Region [21] and also from Southern Ethiopia [16] indicated that most of the dairy farmers were used river water for milk utensils cleaning purpose. However, for production of quality milk a good supply of clean water is essential. Water used for washing and cleaning milk equipment and containers used for milk handling must have the same safety and purity as drinking water [28].

\section{Water Treatment and Utensils Cleaning Practices}

When water from non-tap sources is used for cleaning purpose, it is important that producers should at least filter and heat treat it before use since the quality of water determines the amount of bacterial counts in milk [29]. The majority of the respondents (88.3\%) used cold water for milk utensils cleaning whereas only $11.7 \%$ of them used warm water for similar purpose (Table 6). This might be due to lack of awareness and training about the effect of untreated water used for cleaning activities on milk quality and safety. Similarly, about 75\% $77 \%$ of the respondents washed milk containers with cold water and soap while $23 \%$ used hot water and soap in Borana and West Shewa zone of Oromia Regional State, Ethiopia, respectively [5] [15]. In contrary about $85.6 \%$ of the producers used 
Table 6. Water source, treatment and cleaning practices of milk utensils.

\begin{tabular}{|c|c|c|c|c|c|c|}
\hline \multirow{3}{*}{ Variables } & \multicolumn{4}{|c|}{ Agro-ecology } & \multirow{2}{*}{\multicolumn{2}{|c|}{$\begin{array}{c}\text { Overall Mean } \\
(\mathrm{N}=180)\end{array}$}} \\
\hline & \multicolumn{2}{|c|}{$\mathrm{HL}(\mathrm{N}=90)$} & \multicolumn{2}{|c|}{$\mathrm{ML}(\mathrm{N}=90)$} & & \\
\hline & Freq. & $\%$ & Freq. & $\%$ & Freq. & $\%$ \\
\hline \multicolumn{7}{|l|}{ Source of water } \\
\hline River & 58 & 64.5 & 67 & 74.4 & 125 & 69.4 \\
\hline Tap & 22 & 24.4 & 21 & 23.3 & 43 & 23.9 \\
\hline Well & 10 & 11.1 & 2 & 2.2 & 12 & 6.7 \\
\hline Pond & 0 & 0 & 0 & 0 & 0 & 0 \\
\hline \multicolumn{7}{|l|}{ Heat-treat the water before use } \\
\hline Yes & 11 & 12.2 & 10 & 11.1 & 21 & 11.7 \\
\hline No & 79 & 87.8 & 80 & 88.9 & 159 & 88.3 \\
\hline \multicolumn{7}{|l|}{ Clean the milk container daily } \\
\hline Yes & 73 & 81.1 & 76 & 84.4 & 149 & 82.8 \\
\hline No & 17 & 18.9 & 14 & 15.6 & 31 & 17.2 \\
\hline \multicolumn{7}{|l|}{ Milk container cleaning practice } \\
\hline Washing only & 62 & 68.9 & 42 & 46.7 & 104 & 57.8 \\
\hline Washing then smoking (with weyira) & 28 & 31.1 & 48 & 53.3 & 76 & 42.2 \\
\hline
\end{tabular}

$\mathrm{HL}=$ indicate High Land, $\mathrm{ML}=$ indicate Mid Land and $\mathrm{N}=$ Number of Respondents.

hot water and detergents to clean milk utensils in Hawassa town, Ethiopia [30].

Furthermore, besides to udder infection and water quality, hygienic practices with respect to hand washing, container's cleaning and disinfection are the key areas of milk hygiene intervention [31]. In the current study, about $82.8 \%$ of interviewed households cleaned milk container regularly, whereas the rest $17.2 \%$ of them did not clean regularly (Table 6). In West Shoa Zone, Ethiopia [15] almost all the dairy producers (98\%) and milk collectors washed milk utensils immediately after use.

Smoking of milk handling equipment is a common practice in many parts of Ethiopia. The milk vessels are usually smoked using wood splinters of "Weyira" (Olea africana) to give desirable aroma and flavor to the milk. Smoking isalso found to lower the microbial load of raw milk [32]. However, in the present study areas about $57.8 \%$ of the respondents cleaned milk container by washing without smoking. On the other hand, around $42.2 \%$ of them used both washing and smoking the container with "Weyira" (Olea africana). In comparison, respondents in the midland had more equipment smoking practice than highland area (Table 6). Similarly, many findings reported that Olea africana is the most frequently used plant for smoking of milk containers in different parts of the country [23] [33] [34] [35].

\section{Microbial Quality of Raw Cows' Milk}

Bacterial counts in milk reflect the level of hygiene practiced during milking, milk collection, milk storage temperature, and the time elapsed since milking [36]. 
The current results of total bacterial count (TBC) of milk samples collected from smallholder farmers from the two agro-ecologies, small shops, café and final consumers is indicated in Table 7. The mean TBC was not significantly different $(P<$ $0.05)$ among the milk samples collected from smallholder farmers in the two agro ecologies. However, there was a significance difference $(P<0.05)$ among the milk samples obtained from farm, café and consumers. And there was also marked difference $(P<0.05)$ between milk samples collected from shops and café serving the final consumers (Table 7). The average TBC (5.67 log cfu/mL) found in milk samples collected in this study was failed to comply with the standard set for raw milk intended for direct human consumption (4.6 $\log \mathrm{cfu} / \mathrm{mL})$ [37].

Similarly, high results of TBC $(6.36-9.82 \log \mathrm{cfu} / \mathrm{mL})$ were also reported in different parts of the country [6] [9] [15] [30] [38] [39] [40]. Generally the high counts of bacteria observed in the present study were attributed to lack of awareness related with milk hygiene, low level of educational status, absence of training on clean milk production, udder or teat contamination with unclean barn and bedding materials, lack of cooling facilities at farm and selling points, poor transportation conditions, lack of good hygiene during milking, poor hygiene of milking utensils and milker's hands as well as lack of good hygiene in and around milking environments. Therefore, in order to reduce contamination of milk utensils used for milking should be thoroughly washed, cleaned using detergent and disinfected immediately after use [41].

High numbers of coliform bacteria in the milk generally reflect fecal contamination due to poor hygiene during milking and subsequent handlings, as unclean udder and teats can contribute to the presence of coliform from various sources such as manure, soil, feed, personnel and water [42]. The mean coliform count (CC) was significantly different $(P<0.05)$ among milk samples collected from milk producers of the two agro ecologies and that of milk samples collected from small shops and cafes. On the other hand, there was no marked difference in CC among milk samples collected from two different agro ecologies. Likewise, there was no significant difference between milk samples collected from small shops and cafes serving final consumers (Table 7). Similarly, a CC of milk

Table 7. Means $( \pm$ S.E) of microbial counts $(\log \mathrm{cfu} / \mathrm{ml})$ and $\mathrm{pH}$ of milk collected from producers, sellers and consumers in the district.

\begin{tabular}{ccccc}
\hline \multicolumn{2}{c}{ Variables } & \multicolumn{3}{c}{$($ Mean \pm SE) } \\
\hline Milk sources & Number of samples & TBC & CC & pH \\
\hline Highland HHs & $(\mathrm{n}=15)$ & $5.143 \pm 0.021^{\mathrm{c}}$ & $4.155 \pm 0.024^{\mathrm{b}}$ & $6.167 \pm 0.208^{\mathrm{a}}$ \\
Midland HHs & $(\mathrm{n}=15)$ & $5.165 \pm 0.015^{\mathrm{c}}$ & $4.153 \pm 0.022^{\mathrm{b}}$ & $5.933 \pm 0.058^{\mathrm{b}}$ \\
Shops and Cafés & $(\mathrm{n}=5)$ & $6.186 \pm 0.012^{\mathrm{b}}$ & $5.191 \pm 0.009^{\mathrm{a}}$ & $5.878 \pm 0.034^{\mathrm{b}}$ \\
Consumers & $(\mathrm{n}=5)$ & $6.204 \pm 0.015^{\mathrm{a}}$ & $5.201 \pm 0.011^{\mathrm{a}}$ & $5.874 \pm 0.024^{\mathrm{b}}$ \\
Overall mean & $(\mathrm{N}=40)$ & $5.675 \pm 0.016$ & $4.676 \pm 0.017$ & $5.963 \pm 0.081$ \\
\hline
\end{tabular}

All of the Means followed by different superscripts within columns are significantly different $(P<0.05)$, $\mathrm{HHs}=$ Households, $\mathrm{TBC}=$ Total bacteria count, $\mathrm{CC}=$ Coliform count, $\mathrm{n}=$ number of milk samples, $\mathrm{N}=$ Overall milk samples and S.E $=$ Standard Error. 
samples from West Shewa Zone of Oromia region was $4.49 \mathrm{log} \mathrm{cfu} / \mathrm{ml}[18]$ and $4.84 \log \mathrm{cfu} / \mathrm{mL}$ was reported for milk samples collected from cows kept under traditional condition in the Wolayita zone, southern Ethiopia [43]. Moreover, about $4.18 \pm 0.01 \mathrm{log} \mathrm{cfu} / \mathrm{ml}$ was reported for raw milk samples collected from Bahir Dar milk shed in Amahara region, Ethiopia [19] and $4.10 \mathrm{log} \mathrm{cfu} / \mathrm{ml}$ for milk samples collected in and around Addis Ababa [38]. On the other hand, higher coliform count of $6.57 \mathrm{log} \mathrm{cfu} / \mathrm{ml}$ was reported for raw cow's milk collected from different producers in the central highland of Ethiopia.

In general, the mean values of $\mathrm{CC}$ observed in the present study were much higher when compared with the recommended values set by the American Public Health Service: $<100 \mathrm{cfu} / \mathrm{mL}$ for Grade A milk and $101-200 \mathrm{cfu} / \mathrm{mL}$ for Grade B milk [44]. This higher TBC and CC in the present study might be due to lack of awareness related with hygiene, udder or teat contamination with unclean barn and bedding materials, lack of good hygiene during milking, poor hygiene of milking utensils and milker's hands (possible contamination of milk with fecal materials) unclean udder and teats of cow's, mastitis, improper and low frequency of barn cleaning, and others related factors was observed and assessed during survey work in the study area.

The $\mathrm{pH}$ values higher than 6.8 indicates mastitis milk and $\mathrm{pH}$ values below 6.6 indicates increased acidity of milk due to bacterial multiplication [14]. The overall mean $\mathrm{pH}$ value of milk test in the present study was $5.963 \pm 0.081$ in the district and the mean $\mathrm{pH}$ was significantly different $(P<0.05)$ between milk produced from two agro ecologies. The present study showed that, $6.167 \pm 0.208$ and $5.933 \pm 0.058 \mathrm{pH}$ value for milk from highland and midland agro ecologies, respectively (Table 7). This might be related to udder health problem, number of bacteria at the point of production and level of storage temperature cause for milk fermentation and lactic acid production.

There was marked difference $(P<0.05)$ in $\mathrm{pH}$ values of milk samples from small holder milk producers $(6.05 \pm 0.133)$, and small shops and cafes $(5.878 \pm$ $0.034)$ and consumers $(5.874 \pm 0.024)$ (Table 7). This might be due to extended time between milking and selling to the final consumers, and further exposure of milk to high temperature and contamination. The results of the present study were comparable with the report of [6] who showed that, the mean $\mathrm{pH}$ value of milk as 6.15 in Gurage zone, Southern Ethiopia. However, different mean $\mathrm{pH}$ value of milk (6.49) was reported from Wolaita zone under traditional practices [43] and also reported $\mathrm{pH}$ value of 6.67 which was within the ranges of fresh cow's milk pH while the milk samples obtained from open market (6.10) were not within the normal ranges in Borana Zone of Southern Ethiopia [5].

Milk pH gives an indication of milk hygiene and it usually ranged between 6.6 up to 6.8 when milk temperature is $20^{\circ} \mathrm{C}$ [45]. In general milk pH value obtained from the current study was out of the recommended range for fresh cows' milk. This might due to lack of good hygiene practices, mastitis, contamination at the point of milking, further contamination due to transportation and absence of cooling facilities. 
Table 8. Ranked challenges related with milk hygiene and quality.

\begin{tabular}{ccc}
\hline \multirow{2}{*}{ Variables } & \multicolumn{2}{c}{ Ranked } \\
\cline { 2 - 3 } Lack of clean water & Highland & Midland \\
\hline Lack of knowledge on hygienic practices & $2^{\text {nd }}$ & $2^{\text {nd }}$ \\
Types of bedding materials used & $1^{\text {st }}$ & $1^{\text {st }}$ \\
Types of barn & $5^{\text {th }}$ & $4^{\text {th }}$ \\
Lack of appropriate milking and cooling equipment & $4^{\text {th }}$ & $5^{\text {th }}$ \\
Poor market access & $3^{\text {rd }}$ & $3^{\text {rd }}$ \\
\hline
\end{tabular}

Constraints were ranked based on the number (frequency) of respondents prioritize the problems.

\section{Major Constraints Related to Milk Quality}

The major milk quality related problems ranked based on the response of the sampled respondents and group discussions with key informants from two agro-ecologies were limited knowledge of milk handling, lack of clean water, lack of appropriate milking equipment and cooling facilities (Table 8). Others constraints such as poor bran conditions and poor market access were also ranked as milk quality related problems of the study areas. In consent with the present finding, limited awareness on hygienic handling of milk, lack of cooling facility, shortage of clean water, lack of effective quality control system and absence of quality based payment system were the major milk quality related constraints in Borana and west Shewa zone of Oromia Regional State, Ethiopia [5] [15].

\section{Conclusion}

We found that the physical and microbial quality of milk sampled from the study area was below international and national standards. This is mainly due to lack of good hygienic practices starting from the point of production up until consumption, including materials used for milking, transportation and storage. Therefore, good milk production and handling practices need to be practiced by both the milk producers and stakeholders involved in milk transportation and marketing. Moreover, pertinent tailor-made trainings and awareness creations need to be made to the farming community.

\section{Acknowledgements}

The authors would like to extend their appreciation and acknowledgment to Haramaya University for financial support under Ministry of Education of the Federal Democratic Republic of Ethiopia.

\section{Conflicts of Interest}

The authors declare no conflicts of interest regarding the publication of this paper. 


\section{References}

[1] Lore, T.A., Kurwijila, L.R. and Omore, A. (2006) Hygienic Milk Production: A Training Guide for Farm-Level Workers and Milk Handlers in Eastern Africa. ILRI (International Livestock Research Institute), Nairobi, 1-12.

[2] Pandey, G.S. and Voskuil, C.J. (2011) Manual on Milk Safety, Quality and Hygiene for Dairy Extension Workers and Dairy Farmers, Lusaka, Zambia. 7-26.

[3] Teshome, G. (2013) Physicochemical Properties and Microbial Quality of Raw Cow's Milk Produced and Marketed in Shashemene Town, Southern Ethiopia. MSc Thesis, Haramaya University, Haramaya.

[4] Karmen, G.T. and Slavica, G.T. (2008) The Microbiological Quality of Raw Milk after Introducing the Two Day's Milk Collecting System. Acta Agriculturae Slovenica, 92, 61-74.

[5] Gurmessa, T. (2014) Physicochemical Properties and Microbial Quality of Raw Cow's Milk in Yabello District, Borana Zone, Southern Ethiopia. MSc Thesis, Haramaya University, Haramaya.

[6] Abebe, B., Zelalem, Y. and Ajebu, N. (2012) Hygienic and Microbial Quality of Raw Whole Cow's Milk Produced in Ezha District of the Gurage Zone, Southern Ethiopia. Wudpecker Journal of Agricultural Research, 1, 459-465.

[7] Amistu, K., Melese, A. and Degefa, T. (2015) Evaluation of Hygienic Status and Marketing System of Raw Cow Milk in Different Critical Points of Oromia Special Zone. Global Journal of Science Frontier Research: Biological Science, 15, 21-30.

[8] Holloway, G. and Ehui, S. (2002) Expanding Market Participation among Smallholder Livestock Producers: A Collection of Studies Employing Gibbs Sampling and Data from the Ethiopian Highlands. Socio-Economic and Policy Research Working Paper 48. ILRI, Nairobi.

[9] Zelalem, Y. (2010) Microbial Properties of Ethiopian Marketed Milk and Milk Products and Associated Critical Points of Contamination: An Epidemiological Perspective. Addis Ababa.

[10] Cheha Woreda Agricultural and Rural Development Office (2015) Cheha Woreda Agricultural and Rural Development Office. Unpublished Report.

[11] Richardson, G.H. (1985) Standard Method for the Examination of Dairy Products. 15th Edition, American Public Health Association, Washington DC.

[12] Alganesh, T., Ofodile, L.N. and Fekadu, B. (2007) Microbial Quality and Chemical Composition of Raw Whole Milk from Horro Cattle in East Wollega, Ethiopia.

[13] FDA (Food and Drug Administration) (2003) Food Sampling and Preparation of Sample Homogenate. In: Andrews, W.H. and Hammack, T.S., Eds., Bacteriological Analytical Manual, 8th Edition, Revision A, AOAC, Gaithersburg, Chapter 1.

[14] O’Connor, C.B. (1995) Rural Dairy Technology ILRI Training Manual I. International Livestock Research Institute, Addis Ababa.

[15] Saba, H. (2015) Quality Assessment of Cattle Milk in Adea Berga and Ejerie Districts of West Shoa Zone, Ethiopia. MSc Thesis, Haramaya University, Haramaya.

[16] Abebe, B., Zelalem, Y. and Ajebu, N. (2014) Dairy Production Systems and Constraints in Ezha District of the Gurage Zone, Southern Ethiopia. Global Veterinaria, 12, 181-186.

[17] Tsadkan, Z. (2012) Study on Cattle Milk Production, Processing and Marketing System in Enderta District, Tigray Regional State. MSc Thesis, Addis Ababa University, Addis Ababa. 
[18] Tassew, A. (2007) Production, Handling, Traditional Processing Practices and Quality of Milk in Bahir Dar Milk Shed Area, Ethiopia. M.Sc. Thesis, Haramaya University, Haramaya.

[19] Derese, T. (2008) Present Situation of Urban and Peri-Urban Milk Production and Quality of Raw Milk Produced in West Shewa Zone, Oromia Region. M.Sc. Thesis, Haramaya University, Haramaya.

[20] Asrat, G. (2009) Evaluation of Traditional Practices and Effects of Lactoperoxidase System on Keeping Quality of Cottage Cheese. M.Sc. Thesis, Hawassa University, Hawassa.

[21] Yien, D. (2014) Assessment of Hygienic Milk Production and Prevalence of Mastitis in Dairy Cow in Jikawo Woreda of Nuer Zone, Gambella Region, Ethiopia. MSc Thesis, Addis Ababa University, Addis Ababa.

[22] Gran, H.M., Mutukumira, A.N., Wetlesen, A. and Narvhus, J.A. (2002) Smallholder Dairy Processing in Zimbabwe: Hygienic Practices during Milking and the Microbiological Quality of the Milk at the Farm and on Delivery. Food Control, 13, 41-47. https://doi.org/10.1016/S0956-7135(01)00082-2

[23] Zelalem, Y. and Bernard, F. (2006) Handling and Microbial Load of Cow's Milk and Irgo Fermented Milk Collected from Different Shops and Producers in Central Highlands of Ethiopia. Ethiopian Journal of Animal Production, 6, 67-82.

[24] Islam, M.A., Islam, M.N., Khan, M.A.S., Rashid, M.H. and Obaidullah, S.M. (2009) Effect of Different Hygienic Condition during Milking on Bacterial Count of Cows' Milk. Bangladesh Journal of Animal Science, 38, 108-114. https://doi.org/10.3329/bjas.v38i1-2.9919

[25] Murphy, S.C. (1996) Sources and Causes of High Bacteria Count in Raw Milk: An Abbreviated Review. Cornell University, Ithaca, 1-4.

[26] Karuga, S. (2009) Draft Report on Dairy Chain Analysis, Timau Milk Shed. Micro Enterprise Support Program Trust.

[27] Abebe, B., Zelalem, Y. and Ajebu, N. (2013) Handling, Processing and Utilization of Milk and Milk Products in Ezha District of the Gurage Zone, Southern Ethiopia. Journal Agriculture, Biotechnology and Sustainable Development, 5, 91-98. https://doi.org/10.5897/JABSD2013.0206

[28] Younan, M., Zakaria, F., Matthias, M. and Ragge, D. (2007) Camel Dairy in Somalia Limiting Factors and Development Potential. CH-8092 Zurich, Switzerland. http://www.sciencedirect.com

[29] Zelalem, Y. (2009) Sanitary Conditions and Microbial Qualities of Dairy Products in Urban and Peri-Urban Dairy Shed of the Central Ethiopia. DEA, Lyon.

[30] Haile, W., Zelalem, Y. and Yosef, T.G. (2012) Hygienic Practices and Microbiological Quality of Raw Milk Produced under Different Farm Size in Hawassa, Southern Ethiopia. Agricultural Research and Reviews, 1, 132-142.

[31] Bonfoh, B.C., Roth, A.N., Traore, A., Fane and Farah, Z. (2006) Effect of Washing and Disinfecting Containers on the Microbiological Quality of Fresh Milk Sold in Bamako (Mali). Food Control, 17, 153-161. https://doi.org/10.1016/j.foodcont.2004.09.015

[32] Almaz, G., Foster, H.A. and Holzapfel, W.H. (2001) Field Survey and Literature Review on Traditional Fermented Milk Products of Ethiopia. International Journal of Food Microbiology, 68, 173-186. https://doi.org/10.1016/S0168-1605(01)00492-5

[33] Fekadu, B. (1994) Present Situation and Future Aspects of Milk Production, Milk Handling and Processing of Dairy Products in Southern Ethiopia. Food Production 
Strategies and Limitations: The Case of Aneno, Bulbula and Dongora in Southern Ethiopia. PhD Dissertation, Agricultural University of Norway, Universitetstunet.

[34] Alganesh, T. (2002) Traditional Milk and Milk Products Handling Practices and Raw Milk Quality in Eastern Wollega. M.Sc. Thesis, Alemaya University, Dire Dawa.

[35] Lemma, F. (2004) Assessment of Butter Quality and Butter Making Efficiency of New Churns Compared to Smallholders' Butter Making Techniques in East Shoa Zone of Oromia, Ethiopia. MSc. Thesis, Alemaya University of Agriculture, Dire Dawa, $113 \mathrm{p}$.

[36] Soler, A., Ponsell, C., DePaz, M. and Nunez, M. (1995) The Microbiological Quality of Milk Produced in the Balearic Islands. International Dairy Journal, 5, 69-74. https://doi.org/10.1016/0958-6946(94)P1599-9

[37] Bodman, G.R. and Rice, D.N. (1996) Bacteria in Milk Source and Control. University of Nebraska and United State Department of Agriculture, Lincoln.

[38] Godefay, B. and Molla, B. (2000) Bacteriological Quality of Raw Milk from Four Dairy Farms and Milk Collection Center in and around Addis Ababa. Berliner und Münchener Tierärztliche Wochenschrift, 113, 13.

[39] Debebe, W. (2010) Physicochemical Properties and Safety of Street-Vended Milk in and around Addis Ababa City (Kotebe, Bishoftu and Chancho). M.Sc. Thesis, Haramaya University, Haramaya.

[40] Asaminew, T. and Eyassu, S. (2011) Microbial Quality of Raw Cow's Milk Collected from Farmers and Dairy Cooperatives in Bahir Dar Zuria and Mecha District, Ethiopia. Agriculture and Biology Journal of North America, 2, 29-33.

https://doi.org/10.5251/abjna.2011.2.1.29.33

[41] Dodd, F.H. and Phipps, R.H. (1994) Dairy Management and Health. In: Smith, A.J, Eds., Milk Production in Developing Countries, Centre for Tropical Veterinary Medicine, University of Edinburgh, Scotland, UK, 258-271.

[42] CDC (Center of Disease Control) (2006) Emerging Infectious Diseases.

[43] Rahel, N. (2008) Traditional and Improved Milk and Milk Products Handling Practices and Compositional and Microbial Quality of Milk and Buttermilk in Delbo Watershed of Wolayta Zone. MSc Thesis, Hawassa University, Hawassa.

[44] WHO (World Health Organization) (1997) Global Estimation of Food-Borne Disease. World Health Statistics in Raw Milk, International Dairy Federation, Brussels, $8-11$.

[45] Walstra, P., Geurts, T.J., Noomen, A., Jellema, A. and Van Boekel, M.A.J.S. (1999) Dairy Technology: Principles of Milk Properties and Processes. Marcel Dekker, New York, 149-170. https://doi.org/10.1201/9780824746414 